\title{
The Validity and Reliability of the Perceived Available Support Scale
}

\section{Şahin KAPIKIRAN* Necla ACUN KAPIKIRAN**}

\begin{abstract}
Many scales have been developed to measure social support which is an important area of research. The purpose of this study is to determine the validity and reliability of Perceived Available Support Scale (PASS) which was developed by Schulz and Schwarzer (2003). The Turkish version of PASS was administered to 425 college students in two different studies. Confirmatory factor analysis (CFA) for the scale reached an adequate conformity value. As a result, the scale's factor structure with two subscales of emotional and instrumental was confirmed. Correlation coefficient between anxiety and depression scales with the PASS is computed. A negative significant correlation was found between the PASS with the scores of anxiety and depression scales. Also, there was a positive correlation between PASS and its subscales and the scales of psychological wellbeing. Nevertheless, the results of item-total correlations $(r=.40-.78)$, Cronbach Alfa (.83) and test-retest reliability (.77) showed adequate satisfactory values.
\end{abstract}

Keywords: Perceived Available Support Scale, anxiety, depression, psychological well-being

\footnotetext{
* Assist. Prof. Dr. Pamukkale University Faculty of Education, Department of Psychological Counseling and Guidance. E-mail: skkiran@pau.edu.tr

** Assist. Prof. Dr. Pamukkale University Faculty of Education, Department of Psychological Counseling and Guidance. E-mail: nkkiran@pau.edu.tr
} 


\section{SUMMARY}

Social support has been the focus of many disciplines, such as psychology, psychiatry, social work, nursing, public health and sociology. Social support has four dimensions: emotional, cognitional, social relations and instrumental.

Many scales have been developed to measure social support which is an important area of research. Besides, there has been an increase in the number of studies focusing on social support. The purpose of this study is to calculate the validity and reliability of PASS which was developed by Schulz and Schwarzer (2003).

For the reliability and validity, the Turkish version of PASS was administered to 425 college students, 285 of whom were female and 140 of whom were male in two different studies. In the first study, along with PASS, Beck Inventory of Anxiety, Depression Subscale of the Brief and Symptom Inventory Beck Hopefulness Scale, were used for discriminative validity. In the second study, component validity was administered for Psychological Well-Being Scale (PWBS). In this study, the scale's original items and the model for items that fall in the subscales were confirmed. For computing Perceived Available Support Scale's discriminative reliability, a correlation analysis was carried out between Beck Anxiety Inventory and scores obtained by the subscale of Brief Symptom Depression Inventory and PASS and its subscales. Finally, a statistically significant and negative relationship was found among Instrumental and emotional support with Anxiety scale and Depression scale. The scale's item-total correlations were computed. Results showed that each items' correlation with the total ranged from .40 to .78 and all items were significant at the level of .01. Cronbach alpha scores, computed with the purpose of determining the scale's total and subscales internal reliability, were calculated for Emotional Support $(\alpha=.80)$, and for Instrumental Support $(\alpha=.83)$. The reliability coefficient obtained as a result of administering the scale to 104 students in three-week interval was calculated as test-retest reliability $\mathrm{r}=.77$.

The second study was carried out for computing the component validity of Perceived Available Support Scale. A statistically significant relationship was found between the PASS and its subscales and the Psychological WellBeing Scale. 


\title{
Algılanan Elde Edilebilir Destek Ölçeğinin Türkçeye Uyarlanması: Geçerlik ve Güvenirlik Çalışması
}

\author{
Şahin KAPIKIRAN* Necla ACUN KAPIKIRAN**
}

ÖZ: Bireyin ruh sağlığını koruyucu çalışmalar içinde yer alan, sosyal desteğin ölçümü için çok sayıda ölçek geliştirilmiştir. Bu çalışmanın amacı, Schulz ve Schwarzer (2003) tarafından geliştirilen Algılanan Elde Edilebilir Destek Ölçeği'nin (AEDÖ) geçerlik ve güvenirliğini gerçekleştirmektir. Çalışma, iki farklı katılımcı grup ile yapılmıştır. Birinci çalışma grubunda 224, ikinci çalışma grubunda 201 olmak üzere toplam 425 üniversite öğrencisi yer almıştır. AEED ölçeğinin faktör yapısını belirlemek üzere doğrulayıcı faktör analizi (DFA) yapılmıştır. Ölçeğin hesaplanan DFA uyum indisleri (uyum indisleri) mükemmel düzeye ulaşmıştır. Ölçeğin bileşen ve ayırt edici geçerliği için, kaygı (anksiyete), depresyon ve psikolojik iyi olma ölçek puanları arasında korelasyon hesaplanmıştır. AEED ölçeğinin toplamı ve alt ölçekleri ile Kısa Semptom Envanteri'nin anksiyete alt ölçeği Beck Anksiyete Ölçeği ve Beck Umutsuzluk Ölçeği puanları arasında olumsuz yönde anlamlı ilişki saptanmıştır. AEED toplam ve alt ölçekleri ile Psikolojik İyi Olma alt ölçekleri arasında olumlu yönde ilişki saptanmıştır. Bununla birlikte, ölçeğin madde toplam analizi ( $\mathrm{r}=.40-.78)$, Cronbach Alfa (.83) ve test tekrar test korelasyonu (.77) değerleri kabule dilebilir düzeye erişmiştir.

Anahtar Sözcükler: Algılanan elde edilebilir destek, anksiyete, depresyon, psikolojik iyi olma

\footnotetext{
* Yrd. Doç. Dr. Pamukkale Universitesi Eğitim Fakültesi, Psikolojik Danışma ve Rehberlik Anabilim Dalı. E-posta: skkiran@pau.edu.tr

${ }^{* *}$ Yrd. Doç. Dr. Pamukkale Üniversitesi Eğitim Fakültesi, Psikolojik Danışma ve Rehberlik Anabilim Dalı. E-posta: nkkiran@pau.edu.tr
} 


\section{GİRIŞ}

Sosyal destek, psikoloji, psikiyatri, sosyal çalışma, hemşirelik, halk sağlığı ve sosyoloji gibi çok farklı alandaki bilim insanları için önemli bir çalışma alanı olarak, birçok çalışmanın konusunu oluşturmuş̧tur. Bu alanlar içinde sosyal destek özellikle koruyucu ruh sağlağı anlamında araştırmacıların ilgi alanını oluşturmaktadır. Sosyal destek bireyin işlevlerini artırmaya yönelik ve ya olumsuz sonuçlara karşı tampon görevi sağlayan ebeveyn, öğretmen sınıf arkadaşı, yakın arkadaş ve okul gibi sosyal ağların bireyin davranışlarını destekleme düzeyine ilişkin algı olarak tanımlanır (Malecki ve Demaray 2002; 2006). Cobb(1976)'a göre sosyal destek, sevilme duygusu, değerlilik duygusu ya da saygı görme ve sosyal ağa aitlik olmak üzere üç bileşenden oluşmaktadır. Tardy (1985)'e göre sosyal destek duygusal, bilgi, sosyal ilişki ve araçsal destek olmak üzere dört farklı türden oluşur. Thoits (1982-1995)'e göre duygusal destek, bir kişinin ilgilendiği ve değer verdiği kişinin güvenini pekiştirmek ve içtenlikle destek olmayı içerir. Bilgi desteği, birinin başkasına zorlandığı bir olayı daha iyi anlamasına yardım etme ve başa çıkma stratejileriyle uğraşma, ihtiyaç duyduğu şeylerin ne olduğu hakkında doğrusunu anlatmadır. Araçsal destek, birine ekonomik yardımda bulunma, özel yardımda bulunma ya da iyilik yapma olarak tanımlanır. Son olarak sosyal ilişki boyutu, bir bireyin destek ağlarının bir üyesi olması ile ilişkilidir (Akt. Malecki ve Demaray 2002). Bu boyut sosyal bağl1lık olarak da tanımlanabilir.

Sosyal destek yaşamda karşılaşılan sağlı sorunlarına karşı koruyucudur. Alan yazında hem mental sağlıkla ilgili hem de fiziksel sağlıkla ilgili yapılan çok sayıda çalışma, sosyal desteğin iyileşme sürecine ilişkin katkısına vurgu yapılmıştır. Sosyal destekle ilişkilendirilen, önemli bir ruh sağlığı konusu olan depresyon ve anksiyete arasında olumsuz ilişki kaydedilmiştir (Bayat, Erdem ve Kuzucu, 2008; Cohen ve McKay 1984; Sheets ve Mohr, 2009; Eskin, Ertekin, Harlak ve Dereboy 2008; George, Blazer, Hughes ve Fowler 1989; Horstmanshof, Punch ve Creed 2008; Maher, Mora ve Leventhal, 2006; Yıldırım, 2004). Ayrıca depresyon bozukluğu tanısı almış hastalardan eşlerinden sosyal destek alanların daha hızlı bir iyileşme sürecine girdikleri (Goering, Lancee ve Freeman, 1992) saptanmıştır. Sosyal destek bireyin umutsuzluğunu da azaltan bir faktördür. Örneğin Abramson, Metalsky ve Alloy (1989) yaptıkları bir çalışmada, sosyal desteğin umutsuzluğu önleyen bir olgu olduğunu saptamışlardır. Yine, Uchino, Cacioppoand ve Kiecolt-Glaser (1996) inceledikleri 81 sosyal destekle ilgili çalışmada, sosyal desteğin bireylerin fiziksel sağlığına olumlu katkısı olduğuna dair birçok çalışmaya yer vermişlerdir. Ayrıca, kanser ve kalp hastalarına verilen duygusal ve araçsal sosyal desteğin (Costanzo, Ryff 
and Singer, 2009; Schwarzer, Knoll and Rieckmann 2004) ve Multiple Sekleroz hastalarına verilen sosyal desteğin (Kleiboer, Kuijer, Hox, Schreurs and Bensing, 2006) bu hastaların iyileşmesinde önemli bir rol oynadı̆̆ saptanmıștır. Bundan başka, Beedie ve Kennedy (2002) tarafindan yapılan bir çalışmada omurilik hastaların tedavisi sırasında sosyal destek arttıkça, hastaların umutsuzluk ve depresyonlarının azaldığını rapor etmişlerdir.

Sosyal desteğin ruhsal ve fiziksel sağlık problemleri gibi olumsuz yaşam olaylarıyla olan ilişkisinin yanında olumlu yaşam olayları ile de ilişkisi geniş ölçüde araştırılmıştır. Örneğin, psikolojik iyi olma, öznel iyi olma ve /veya yaşam doyumu ile sosyal destek arasında olumlu yönde ilişkiyi araştıran çok sayıda araştırmaya rastlanmıştır. Bu çalışmaların tamamında sosyal destek ile psikolojik iyi olma, öznel iyi olma ve yaşam doyumu, olumlu yaşam olaylarıyla olumlu yönde ilişki kaydedilmiştir (Beedie ve Kennedy 2002; Burris, Brechting, Salsman and Carlson, 2009; Cohen ve McKay, 1984; Cummings, 2002; Danielsena, Samdal, Hetland ve Wold, 2009; Demaray ve Malecki, 2002; Edwards ve Lopez, 2006; Horstmanshof ve ark., 2008; ; Lambert, Lambert, Klipple and Mewshaw, 1990; Maher ve ark., 2006; Sheets ve Mohr, 2009; Wilson, 2006; Y1ldırım 2004; Zimet, Dahlem, Zimet ve Farley,1988). Bununla birlikte sosyal destek, bireyin kendini olumlu görmesine ve problemlerle karşılaştığında onunla mücadele etme azminin artmasına da neden olmaktadır (Greenglass ve Fiksenb, 2009). Bundan başka sosyal destek, benlik saygısı (Demaray ve Malecki 2002; Wentworth ve Parks, 2006), özerklik ve bağlilıkla (Ratella, Larose, Guay ve Senecal, 2005) olumlu olarak ilişkilidir.

Sosyal desteğin cinsiyetler arasında fark yaratıp yaratmadığına ilişkin incelemelerde, algılanan sosyal desteğin miktarı, türü ve yararlanma düzeyi bakımından farklı sonuçlar elde edilmiştir. Örneğin kadınların erkeklerden daha fazla sosyal destek aldığı kaydedilmiştir (Kapıkıran ve Özgüngör 2009; Lopez, Ehly, ve Vazquez-Garcia, 2002; Malecki ve Demaray 2003). Üstelik, kadınların aldığ 1 sosyal destekten yararlanma düzeyi, erkeklerden daha fazladır (Lopez ve ark., 2002; Malecki ve Demaray 2006 ). Buna karşılık, algılanan duygusal sosyal desteğin kadınlardan çok erkeklere verildiği saptanmıştır (Schmidt, Klessig ve Pufahl 2006).

Sosyal destekle ilgili çok sayıda araştırmanın yapılmasına paralel olarak, alan yazında çok sayıda sosyal destek ölçeği geliştirilmiştir. Bunlar, Sosyal Destek Davranışları Envanteri (Barrera ve Ainlay, 1983), Çok Yönlü Algıllanan Elde Edilebilir Destek Ölçeği (Zimet ve ark. 1988), Sosyal Destek Davranışları Ölçeği (Vaux Phillips, Thomson, Holly, Williams ve Stewart, 1986), Berlin Sosyal Destek Ölçeği (Schulz ve Schwarzer, 2003), Çocuk ve 
Ergenler için Sosyal Destek Ölçeği (Malecki ve Demaray 2002), Özel İlişkilerde Alınan Destek Ölçeği (Barry ve ark. 2009), Algılanan Topluluk Desteği Ölçeği (Herrero ve Gracia, 2007), Algılanan Aile Örgüt Desteği Ölçeği (Jahn, Thompson ve Kopelman, 2003), Sosyal Destek Duygusu Ölçeği (Dolbier ve Steinhardt 2000), Algılanan Sosyal Destek Ölçeği (Yıldırım, 2004a). Burada yer alanların dışında dünyada farklı sosyal destek ölçeklerinin varlığı da olasıdır. Bu durum sosyal desteğin ne derece önemli bir çalışma alanı olduğunun bir kanıtı sayılabilir. Bu ölçeklerin her birini diğerinden farklı kılan sosyal desteğin türü, sosyal destek ağı, sosyal desteğin ölçümünde kullanılan soru miktarı gibi değişkenlerdir.

Ülkemizde sosyal desteğin ölçümünde kullanılan az sayıda ölçek bulunmakta olup, ulaşılan bu ölçekler ise yalnızca sosyal destek ağlarını ölçmeye yönelik olduğu görülmüştür. (Eker ve Arkar 1995; Yıldırım 2004a; Gökler 2007;. Eskin ve ark. 2008; Gün ve Bayraktar, 2008;). Sosyal desteğin elde edildiği sosyal ağ kadar, alınan sosyal desteğin türü de önemli olabilir. Özellikle elde edilen duygusal destek, fiziksel ve ruhsal hastalıkları olan hastaların iyileşmelerinde önemli bir işleve sahiptir (Costanzo ve ark. 2006; Schwarzer ve ark. 2004).

Mevcut çalışmanın amacı, Berlin Sosyal Destek Ölçeklerinden, Algılanan Elde Edilebilir Destek Ölçeğinin Türkçeye uyarlanmasıdır. Bu ölçek, sosyal desteğin türleri arasında yer alan duygusal ve araçsal sosyal desteği ölçmeyi amaçlamaktadır. Bu ölçeğin seçiminde, ölçek madde sayısının azlığ1 ve duygusal-araçsal sosyal destek türlerini ölçmesi etken olmuştur. Algılanan Elde Edilebilir Destek Ölçeğinin Türkçeye uyarlama çalışması iki farklı grupla gerçekleştirilmiştir. Bu iki grupta yer alan üniversite öğrencileri tamamen farklıdır. Diğer bir deyişle, birinci grubu oluşturan gruplar ile ikinci grubu oluşturan grupta yer alan öğrenciler farklı bölümlerde öğrenim görmektedirler. İki farklı çalışmanın yapılma nedenlerinden birisi, soru maddelerini yanttlayan katılımcıların aynı anda çok sayıda soru maddesini yanıtlamadaki isteksizliğinden dolayı soru maddelerini rastgele işaretleme olasılığıdır. İkinci nedeni, çalışmanın farklı grupta da benzer psikometrik özelliklerine sahip olup olmadığını test etmektir.

\section{Birinci Çalışma}

Birinci çalışmanın amacı (a) ölçeğinin orijinal faktör yapısını belirlemek üzere, orijinal yapı kriter alınarak doğrulayıcı faktör analizi, (b) ölçeğin ayırdedici geçerliği için Beck Anksiyete Envanteri Kısa Semptom Envanterinin depresyon alt ölçeği ve Beck Umutsuzluk Ölçeği puanları ile korelasyonu, (c) ölçeğin zaman içinde değişmezlik güvenirliği için, test yeniden test korelasyonu (d) iç tutarlılık güvenirliği için cronbach alfa katsayısı ve (e) madde toplam puan korelasyon analizinin yapılmasıdır. 


\section{YÖNTEM}

\section{Katılımcılar}

Birinci çalışma grubu, Pamukkale Üniversitesi Eğitim Fakültesinin farklı bölümlerinde öğrenim gören 166 kı (\%74) 58 erkek (\%26) olmak üzere toplam 224 öğrencidir. Öğrencilerin yaşları 18 ile 26 arasında (Ort. 20.65) değişmektedir.

\section{Veri Toplama Araçları}

\section{Algılanan Elde Edilebilir Destek Ölçeği (AEDÖ)}

Algılanan Elde Edilebilir Destek Ölçeği, Schulz ve Schwarzer (2003) tarafından geliştirilen Berlin Sosyal Destek Ölçeklerinin bir boyutudur. Berlin Sosyal Destek Ölçekleri Algılanan Elde Edilebilir Destek(AED), Destek Arama, Destek Gereksinimi Gerçek Alınan Destek (sağlayıc1), Gerçek Alınan Destek (alıc1) ve Koruyucu Tampon Ölçeği olmak üzere 6 ölçekten oluşmaktadır. Ölçekler Almanyada hem normal hemde hasta grupları üzerinde geçerliği ve güvenirliği yapılmıştır. Bu ölçeklerin her biri ayrı ayrı puanlanmaktadır. Dolayısıyla her biri ayrı bir ölçek olarak değerlendirilmektedir. Algılanan Elde Edilebilir Destek Ölçeği 8 maddeli, duygusal ve araçsal olmak üzere iki alt ölçekten oluşmaktadır. Ölçek hiç uygun değil (1) ile tamamen uygun (4) arasında değişen 4'lü likert türünden yanıtlamayı gerektirmektedir. AED ölçeği için cronbach alfa değeri .83 olarak hesaplanmıştır. Ölçeklerin hem İngilizce hemde Almanca formu vardır. Bu çalışmada ölçeğin İngilizce formunun çevri ve geri çevri işlemleri yapılmıştır.

\section{Beck Anksiyete Envanteri (BEA)}

Ölçek Beck ve ark. (1988) tarafından geliştirilmiştir. Türkçeye uyarlama çalışması Ulusoy ve ark. (1996) tarafından yapılmıştır. Beck Anksiyete Envanteri bireylerin yaşadığı anksiyete belirtilerinin sıklığının belirlenmesi için hazırlanmış, 21 maddeden oluşan 0-3 arası puanlanan likert tipi bir ölçektir. Ölçekten alınan toplam puanların yüksekliği, bireyin yaşadığ1 anksiyetenin yüksekliğini göstermektedir. Psikiyatrik hastalardan oluşan bir araştırma grubu üzerinde yapılan çalışmada ölçeğin Cronbach Alfa iç tutarlılık katsayısı .93 olarak bulunmuştur (Savaşır ve Şahin, 1997).

\section{Beck Umutsuzluk Ölçeği (BUÖ)}

Ölçek Beck ve ark.(1974) tarafından geliştirilmiş olup 20 maddeden oluşmaktadır. Ölçek evet ve hayır türünden işaretlemeyi gerektirmektedir. Türkçeye uyarlaması Seber (1991) ve Durak(1994) tarafından yapılmış olan ölçeğin Cronbach Alfa değeri .55 ile .86 arasında değişmektedir. Ölçek 
gelecekle ilgili duygular ve beklentiler, güdü kaybı ve umut olmak üzere üç alt ölçekten oluşmuştur(Savaşır ve Şahin, 1997).

\section{Kısa Semptom Envanteri (KSE)}

Ölçek Derogatis(1992) tarafından geliştirilmiş olup Türkçeye uyarlamak amacıyla geçerlilik ve güvenilirliği Şahin ve Durak (1994) tarafından yapılmıştır. Kısa Semptom Envanteri çeşitli psikolojik belirtileri taramak amaciyla ergen ve yetişkinlere uygulanabilen bir kendini değerlendirme ölçeğidir. Beş alt ölçekten oluşmaktadır. $\mathrm{Bu}$ çalışmada depresyon alt ölçeği kullanılmıştır. Depresyon ölçeği için $\alpha=.81$ olarak hesaplanmıştır (Savaşır ve Şahin, 1997).

\section{İșlem}

$\mathrm{Bu}$ çalışmada Algılanan Elde Edilebilir Destek Ölçeğinin geçerlik ve güvenirliği yapılmadan önce, ölçeğin geliştiricileri (Schulz ve Schwarzer, 2003) arasında yer alan Dr.Ralf Schwarzer'den izin alınmıştır. Daha sonra, orijinali İngilizce olan ölçek soru maddeleri İngilizce ve Türkçeyi iyi bilen üç öğretim elemanı tarafından Türkçeye çeviri ve geri çeviri çalışması yapılmıştır. Ölçek çeşitli psikoloji ve rehberlik dersleri kapsamında gönüllü olduğunu ifade eden öğrencilere uygulanmıştır. Ölçeklerin ugulaması yaklaşı 20 dakika sürmüştür. Elde edilen verilerin analizinde, SPSS 14.0 ve Lisrel 8.71 paket programları kullanılmıştır.

\section{BULGULAR}

$\mathrm{Bu}$ çalışmada sırasıyla (a) orijinal ölçek formunun faktör yapısının Türkçe ölçek formu ile benzer faktör yapısında olup olmadığı, (b) ölçeğin ayrıdedici geçerliği için Beck Anksiyete Ölçeği puanları, KSE depresyon alt ölçek puanları ve Beck Umutsuzluk Ölçeği puanları ile korelasyonu, (c) ölçeğin test tekrar test güvenirliği, (d) cronbach alfa güvenirliği ve (e) madde toplam güvenirlik kat sayıları hesaplanacaktır.

\section{Geçerlik}

\section{Doğrulayıcı Faktör Analizi}

Elde edilen verilerin analizinde doğrulayıcı faktör analizi için Lisrel 8.71 programı (Joreskog ve Sorbom 2004) kullanılmıştır. Orijinal ölçek yapısının uygunluğunu test etmek için, orijinal ölçekteki model kullanılmıştır. Alan yazında, bir modelin uygunluğuna ilişkin çok sayıda uyum indeksi vardır.

Alan yazında test edilen modelin, analiz edilen veriyle uyumunu sınamak için kullanılan en yaygın uygulamalar arasında ki kare, serbestlik 
derecesi, sınanan modelin Karşılaştırmalı Uyum İndeksi (Comperative Fit Index) CFI, modelin açıklanan kovaryans ile gözlenen kovaryansları arasındaki farkların ortalamasını veren Standardize Edilmiş Hataların Ortalama Karakökü (Standartized Root Mean Square Resudual) SRMR, Yaklaşık Hataların Ortalama Kare Kökü (Root Mean Square Error of Approximation) RMSEA, modelin karmaşıklığını dikkate alan bir değer olan Normalleştirilmemiş Uyum İndeksi (Non-Normed Fit Index/ Tucker-Lewis Index) NNFI ve Uyum İyiliği İndeksi (Goodness of Fit Index) GFI kullanılmaktadır. Elde edilen verilerin modele uygunluğunu belirlemek amacıyla kullanılan ki kare 'p' değerinin anlamlı olmaması ve serbestlik derecesinin ise 2'nin altında olması beklenir (Kelloway 1998; Şimşek 2007) Ayrıca, uyum indekslerinden RMSEA ve SRMR .08 ya da daha az bir değer (Hu ve Bentler, 1999) model için kabul edilebilir uyumun göstergesi olarak kabul edilir. SRMR ve RMSEA'nın değeri .05 ya da daha az ise iyi bir uyumun göstergesi olarak kabul edilir (Hu ve Bentler, 1999, Şimşek 2007). CFI, NFI, NNFI, GFI, AGFI uyum indeksleri .90 kabul edilebilir, .95 ve üstü iyi bir uyum indeksi olarak kabul edilir (Hu ve Bentler, 1999).

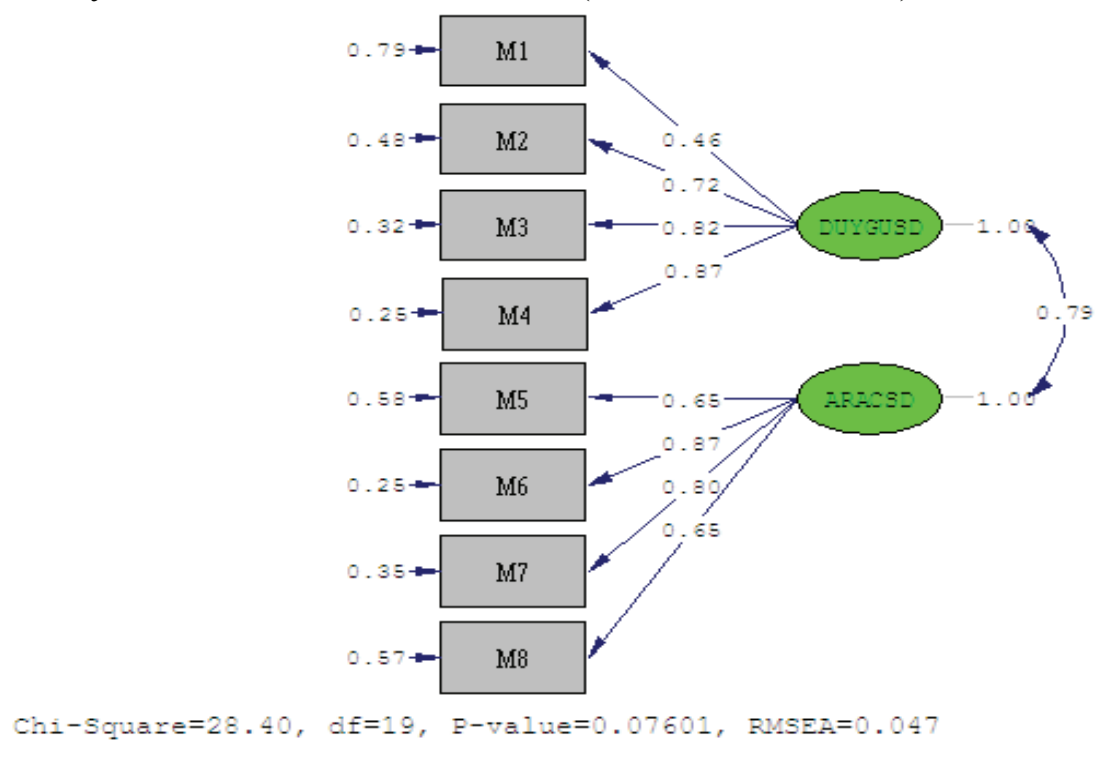

Şekil 1. Algılanan elde edilebilir destek ölçeğinin standardize edilmiş değerlere iliskin yol analizi

Orijinal ölçek iki alt ölçekten oluşmaktadır. Bu alt ölçekler birbirinden bağımsız iki faktör yapısına sahip olup olmadığını belirlemek için model ayrı ayrı sınanmıştır. Duygusal SD ölçeğine ilişkin model sınanması 
sonucunda $\mathrm{X}^{2}=(2, \mathrm{~N}=224) \quad 1.22, \mathrm{p}>.05 \quad \mathrm{RMSEA}=0.01, \quad \mathrm{SRMR}=0.01$, $\mathrm{CFI}=1.00$ ve $\mathrm{GFI}=1.00, \mathrm{NFI}=1.00, \mathrm{NNFI}=1.01$ ile mükemmel düzeyde uyum değerlerine sahip olduğu saptanmıştır.

Araçsal SD ölçeği için $\mathrm{X}^{2}=(2, \mathrm{~N}=224)$ 1.61, $\mathrm{p}>.05$ RMSEA=0.01, $\mathrm{SRMR}=0.01, \mathrm{CFI}=1.00$ ve $\mathrm{GFI}=1.00, \mathrm{NFI}=1.00, \mathrm{NNFI}=1.01$ ile mükemmel düzeyde uyum değerlerine sahip olduğu saptanmıştır.

Ölçeklerin tek bir Model ile sinanması sonucunda $\mathrm{X}^{2}=(19, \mathrm{~N}=224)$ 28.40, RMSEA $=0.047, \mathrm{SRMR}=0.040, \mathrm{CFI}=.99$ ve $\mathrm{GFI}=.99, \mathrm{NFI}=.99$, $\mathrm{NNFI}=.99$ ile iyi düzeyde uyum değerlerine sahip olduğu saptanmıştır.

Ölçeğin modele uygunluğu için yapılan yapısal eşitlik modeline dayalı DFA testinde elde edilen bir diğer sonuç, örtük değişkenlerle yol analizidir. Ölçeğin örtük değişkenlere ilişkin standardize edilmiş değerlere ilişkin yol analizi şekil 1'de görülmektedir. Şekil 1'de görüldüğü gibi en düşük faktör yükü .46 ve en yüksek faktör yükü .87 'dir. Tüm analiz sonuçları değerlendirildiğinde, ölçeğin faktör yapısının bu modeli iyi bir şekilde yansittığı ifade edilebilir.

Tablo 1'de DFA üzerinde elde edilen maddelerin çoklu korelasyon kareleri, $t$ değerleri, standardize edilmiş lambda-X değerleri, madde toplam korelasyonları ve aritmetik ortalamaları görülmektedir. Elde edilen tüm değerler .001 düzeyinde anlamlıdır. Bu sonuçlar bağlamında, ölçeğin faktör yapısı orijinal ölçek ile uyumlu bir yapıdadır.

Tablo 1. Algılanan elde edilebilir destek ölçek maddelerinin $R^{2}$ t değerleri $\lambda x$ ve madde toplam korelasyonlarl, alfa değerleri

\begin{tabular}{|c|c|c|c|c|c|c|}
\hline $\mathrm{Mad}$ & $\mathrm{R}^{2}$ & $\mathrm{t}$ & $\lambda x$ & $\bar{x}$ & $\begin{array}{l}\text { Mad. Top. } \\
\text { r }\end{array}$ & $\alpha$ \\
\hline M1 & 0.21 & 6.78 & .46 & 3.429 & .40 & .85 \\
\hline M2 & 0.52 & 11.89 & .72 & 3.112 & .64 & .74 \\
\hline M3 & 0.68 & 14.29 & .82 & 3.192 & .71 & .71 \\
\hline M4 & 0.75 & 15.44 & .87 & 3.268 & .73 & .69 \\
\hline M5 & 0.42 & 10.38 & .65 & 3.585 & .59 & .82 \\
\hline M6 & 0.75 & 15.46 & .87 & 3.464 & .74 & .75 \\
\hline M7 & 0.65 & 13.82 & .80 & 3.411 & .72 & .76 \\
\hline M8 & 0.43 & 10.41 & .65 & 3.384 & .59 & .82 \\
\hline
\end{tabular}

\section{Aytrt Edici Geçerlik}

Algılanan Elde Edilebilir Destek Ölçeğinin ayırt edici geçerliği için, Beck Anksiyete Envanteri ve Kisa Semptom Envanteri'nin depresyon alt 
öçeklerinden elde edilen puanlarla AEDÖ ve alt ölçekleri arasında korelasyon analizi yapılmıştır.

Tablo 2'de görüldüğü gibi, duygusal sosyal destek ile Beck Anksiyete Ölçeği puanları arasında $(\mathrm{r}=-.19, \mathrm{p}<.01)$ ve KSE depresyon alt ölçeği puanları ile $(\mathrm{r}=.31, \mathrm{p}<.01)$ olumsuz yönde anlamlı ilişki kaydedilmiştir. Ancak, Beck Umutsuzluk Ölçeği puanları ile ( $r=-.12, p>.05)$ anlamlı ilişki bulunmamıştır. Araçsal sosyal destek ile Beck anksiyete puanları arasında ( $\mathrm{r}$ $=-.20, \mathrm{p}<.01)$, KSE depresyon alt ölçeği puanları ile $\mathrm{r}=-.26, \mathrm{p}<.01)$ ve Beck umutsuzluk ölçek puanları ile $(\mathrm{r}=-.17, \mathrm{p}<.05)$ olumsuz yönde anlamlı ilişki bulunmuştur. Algilanan Elde Edilebilir Destek Ölçeği ile Anksiyete Ölçeği arasinda $(\mathrm{r}=-.21, \mathrm{p}<.01$, depresyon ile $(\mathrm{r}=-.31, \mathrm{p}<.01)$ ve Beck Umutsuzluk Ölçeği puanları ile $(\mathrm{r}=-.16, \mathrm{p}<.05) \quad$ olumsuz yönde anlamlı ilişki saptanmıştır.

Tablo 2. Algllanan elde edilebilir destek ölçeği ve alt ölçeklerinin çeşitli değişkenlerle korelasyonu

\begin{tabular}{llll}
\hline & $\begin{array}{l}\text { Duygusal } \\
\text { Sosyal Destek }\end{array}$ & $\begin{array}{l}\text { Araçsal } \\
\text { Sosyal Destek }\end{array}$ & AEEDToplam \\
\hline Duygusal Sosyal Destek & 1 &, $68 * *$ &, $92^{* *}$ \\
Araçsal Sosyal Destek &, $68 * *$ & 1 &, $91 * *$ \\
AEED Toplam &, $92 * *$ &, $91 * *$ & 1 \\
Anksiyete &,$- 19 * *$ &,$- 20 * *$ &,$- 21 * *$ \\
Depresyon &,$- 31 * *$ &,$- 26 * *$ &,$- 31 * *$ \\
Umutsuzluk & -.12 & $-.17,08$ & $-.16^{*}-, 03$ \\
\hline$* 05 ; * * .01$ & & &
\end{tabular}

AEDD = Alg1lanan Elde Edilebilir Destek

Kız ve erkekler arasında fark olup olmadığını belirlemek üzere tek yönlü varyans analizi yapılmıştır. Sonuçta, hem duygusal sosyal destek (kız $X=13,39$, sd: 2,26; erkek $X=11,88$, Sd: $2.52, F: 5.937, p<.05)$ ve hem de araçsal sosyal destek ( $\mathrm{k} 1 \mathrm{X} \mathrm{X}=14.06$, sd: 2.23 ; erkek $\mathrm{x}=13.22$, $\mathrm{Sd}$ : 2.32 , F: $18.069, \mathrm{p}<.001)$ puanları bakımından anlamlı düzeyde fark yaratmıștır. $\mathrm{Bu}$ sonuca göre, kızlar duygusal ve araçsal sosyal destek bakımından erkeklerden daha fazla puan almışlardır. Diğer bir deyişle, kızlar erkeklerden daha fazla duygusal ve araçsal sosyal destek almaktadırlar.

\section{Güvenirlik}

\section{Madde Toplam Puan Korelasyonu}

Ölçek maddelerinin güvenirliğini ölçmek amacıyla yapılan madde toplam puan korelasyonu, .40 ile .74 arasında değişmekte olup tüm maddeler .01 düzeyinde anlamlıdır. 


\section{Alfa Değerleri}

Ölçeğin toplam ve alt ölçeklerinin içsel güvenirliğini belirlemek için yapılan cronbach alfa değerleri tüm ölçek için $\alpha=.88$, Duygusal Sosyal Destek Alt Ölçeği için $\alpha=.80$, ve Araçsal Sosyal Destek Alt Ölçeği için $\alpha=$ .83 olarak hesaplanmıştır.

\section{Test Tekrar Test}

Ölçeğin zamanla değişmezlik güvenirliği için üç hafta arayla test tekrar test yapılmıştır. Duygusal SD alt ölçeği için .74 Araçsal SD için .65 tüm ölçek için .77 korelasyon hesaplanmıştır. Ölçeklerin test tekrar testi için birinci uygulama verileri birinci çalışma katılımcıları içinde yer almıştır.

Özetle bu çalışmada ölçeğin faktör yapısını doğrulamak amacıyla yapılan DFA sonucu, ölçüm değerlerinin yeterli olduğu saptanmıştır. Ayrıca, ölçeğin ayırt edici geçerliği için kullanılan depresyon ve anksiyete ölçeklerinin puanları arasında orta düzeyde, umutsuzluk ölçek puanları arasında ise düşük düzeyde bir ilişki saptanmıştır. Dahası, ölçeğin güvenirliği için cronbach alfa ve test tekrar test sonuçlarının yüksek düzeyde olduğu kaydedilmiştir.

\section{İkinci Çalışma}

Bu çalışmanın amacı, ölçeğin psikometrik özellikleri bakımından güçlü bir ölçek olup olmadığını belirlemektir. Bu amaçla (a) ölçeğin faktör yapısını belirlemek üzere, orijinal yapı ve birinci çalışma sonucu kriter alınarak doğrulayıcı faktör analizi, (b) ölçeğin ayırdedici geçerliği için Psikolojik İyi Olma ölçeği puanları ile korelasyonu, (c) iç tutarlılık güvenirliği için cronbach alfa katsayısı ve (d) madde toplam puan korelasyon analizi yapilacaktır.

\section{YÖNTEM}

İkinci katılımcı grup Pamukkale Üniversitesi Eğitim Fakültesinin farklı bölümlerinde okuyan $119 \mathrm{k1z}(\% 59.2)$ ve 82'si erkek (\%40.8) olmak üzere toplam 201 öğrenciden oluşmaktadır. Öğrencilerin yaşları 16.6 ile 25.0 arasında değişmektedir (ort. $=20.75$ ).

\section{Veri Toplama Araçları}

\section{Algılanan Elde Edilebilir Destek Ölçeği (AEDÖ)}

Schulz ve Schwarzer (2003) tarafindan geliştirilen Algılanan Elde Edilebilir Destek Ölçeğine ilişkin bilgiler, birinci çalışmada verilmiştir. 


\section{Psikolojik İyi Olma Ölçeği (PİÖ)}

Ryff (1989a) tarafindan geliştirilen 'Psikolojik İyi Olma Ölçeği 84 maddedir. Ölçek,özerklik, çevresel hakimiyet, bireysel gelişim, diğerleriyle olumlu ilişkiler, öz kabul olmak üzere altı alt ölçekten oluşmaktadır. Türkçeye uyarlama çalışması Cenkseven (2007) ve Akın (2008) tarafından gerçekleştirilmiş̧ir. Cenkseven(2007) çalışmasında ölçeğin Cronbach alfa katsayısı .74 ile .77 arasında değişmektedir. Akın (2008) çalışmasında, ölçeğin Cronbach alfa katsayısı özerklik alt ölçeği için .94, çevresel hakimiyet için .97, bireysel gelişim için .97, diğerleriyle olumlu ilişkiler için .96, yaşam amaçları için .96 ve kendini kabul için .95 olarak saptanmıştır. Ölçeğin dört hafta arayla yapılan test-tekrar test güvenirlik katsayıları .78 ile .97 arasında değişmektedir. Ölçeğin madde toplam korelasyonları ise .32 ile .90 arasında sıralanmıştır.

\section{İșlem}

Bu çalışmada 201 gönüllü üniversite öğrencisine uygulanan Algılanan Elde Edilebilir Destek Ölçeği ile birlikte Psikolojik İyi Olma Ölçeği uygulanmıştır. Elde edilen veriler SPSS 14.0 ve LISREL 8.71 paket programları ile analiz edilmiştir.

Tablo 3. Algllanan elde edilebilir destek ölçeği ve alt ölçeklerinin psikolojik iyi olma ölçeği alt ölçekleri arasındaki korelasyonlar

\begin{tabular}{llll}
\hline & Duygusal SD & Araçsal SD & AEEDToplam \\
\hline Duygusal Sosyal Destek & 1 & $.60^{* *}$ & $.90^{* *}$ \\
Araçsal Sosyal Destek & $.60^{* *}$ & 1 & $.90^{* *}$ \\
AEED Toplam & $.90^{* *}$ & $.90^{* *}$ & 1 \\
Psikolojik İyi Olma Toplam & $.45^{* *}$ & $.46^{* *}$ & $.51^{* *}$ \\
Diğerleriyle Olumlu Bir İlişkiler & $.52^{* *}$ & $.50^{* *}$ & $.57^{* *}$ \\
Otonomi & $.17^{*}$ & .13 & $.17^{*}$ \\
Çevresel Hakimiyet & $.41^{* *}$ & $.43^{* *}$ & $.47^{* *}$ \\
Bireysel Gelişim & $.28^{* *}$ & $.29^{* *}$ & $.32^{* *}$ \\
Yaşam Amaci & $.35^{* *}$ & $.39^{* *}$ & $.42^{* *}$ \\
Kendini Kabul & $.38^{* *}$ & $.41^{* *}$ & $.44^{* *}$ \\
\hline
\end{tabular}

$* .05 \quad * * .01$

\section{AEED = AlgIlanan elde edilebilir Destek \\ BULGULAR}

Bu çalışmada, (a) birinci çalışmada elde edilen faktör yapısı ile benzer yapıda olup olmadığı, (b) ölçeğin bileşen geçerliği için psikolojik iyi olma alt ölçekleri ile korelasyonu, (c) cronbach alfa güvenirliği ve (d) ölçek maddelerinin toplam güvenirlik kat sayıları hesaplanmıştır. 


\section{Bileşen Geçerliği}

AEEDÖ toplam puan ve alt ölçekleri ile Psikolojik İyi Olma Ölçeğinin alt ölçekleri arasında hesaplanan korelasyonlar tablo 4'de verilmiştir. Tabloya göre, AEEDÖ toplam ile Psikolojik İyi Olma Ölçeği arasında ( $\mathrm{r}=$ $.51, \mathrm{p}<.01)$ ve AEEDÖ'nin alt ölçeklerinden duygusal sosyal destek alt ölçeği ile PİOÖ $(r=.45, \mathrm{p}<.01)$ ve araçsal sosyal destek alt ölçeği ile PİÖ arasında $(\mathrm{r}=.46, \mathrm{p}<.01)$ anlamlı düzeyde ilişki kaydedilmiştir. AEDÖ toplam ile PİÖ'nin alt ölçeklerinden diğerleriyle olumlu ilişkiler kurma alt ölçeği $(\mathrm{r}=.57, \mathrm{p}<.01)$, otonomi alt ölçeği $(\mathrm{r}=.17 \mathrm{p}<.05)$, çevresel hakimiyet alt ölçeği $(r=.47, p<.01)$, bireysel gelişim alt ölçeği $(r=.32, p<.01)$, yarışmacılık alt ölçeği $(r=.42, p<.01)$ ve kendini kabul alt ölçeği $(r=.44$, $\mathrm{p}<.01)$ arasında anlamlı yönde ilişki saptanmıştır. AEEDÖ'nin duygusal sosyal destek alt ölçeği ile PİOÖ'nin diğerleriyle olumlu ilişkiler kurma altölçeği $(\mathrm{r}=.52, \mathrm{p}<.01)$, otonomi alt ölçeği $(\mathrm{r}=.17, \mathrm{p}<.05)$, çevresel hakimiyet alt ölçeği $(\mathrm{r}=.41, \mathrm{p}<.01)$, bireysel gelişim alt ölçeği $(\mathrm{r}=.28$, $\mathrm{p}<.01)$, yarışmacılık alt ölçeği $(\mathrm{r}=.35, \mathrm{p}<.01)$ ve kendini kabul alt ölçeği $(\mathrm{r}$ $=.38, \mathrm{p}<.01)$ arasında anlamlı ilişki hesaplanmıştır. Bununla beraber, AEEDÖ'nin araçsal sosyal alt ölçeği ile PIOOÖ'nin diğerleriyle olumlu ilişkiler kurma alt ölçeği arasında $(\mathrm{r}=.50, \mathrm{p}<.01)$, çevresel hakimiyet alt ölçeği $(\mathrm{r}=.43, \mathrm{p}<.01)$, bireysel gelişim alt ölçeği $(\mathrm{r}=.29, \mathrm{p}<.01)$, yarışmacılık alt ölçeği $(r=.39 \mathrm{p}<.01)$ ve kendini kabul alt ölçeği arasında $(r$ $=.41, \mathrm{p}<.01)$ anlamlı biçimde ilişki vardır. Ancak AEEDÖ'nin araçsal sosyal destek alt ölçeği ile PİOÖ’nin otonomi alt ölçeği arasında $(r=.13$, $\mathrm{p}<.05$ ) anlamlı ilişki kaydedilmemiştir.

Tablo 4. Algılanan elde edilebilir destek ölçek maddelerinin $R^{2} t$ değerleri standardize $\lambda x$ madde toplam korelasyonları alfa değerleri

\begin{tabular}{|c|c|c|c|c|c|c|}
\hline Mad & $\begin{array}{l}\text { Varyans } \\
\left(\mathrm{R}^{2)}\right.\end{array}$ & $\mathrm{t}$ & $\lambda x$ & $\bar{X}$ & $\begin{array}{l}\text { Mad. } \\
\text { Top. r }\end{array}$ & $\alpha$ \\
\hline M1 & 0.32 & 8.31 & .56 & 3,438 & .33 & ,71 \\
\hline M2 & 0.68 & 13.77 & .82 & 3,000 & .50 & ,68 \\
\hline M3 & 0.80 & 15.59 & .89 & 3,134 & .58 & 67 \\
\hline M4 & 0.51 & 11.30 & .72 & 3,284 & .30 & ,78 \\
\hline M5 & 0.59 & 12.66 & .77 & 3,542 & .60 & ,89 \\
\hline M6 & 0.81 & 16.32 & .90 & 3,333 & .77 & ,83 \\
\hline M7 & 0.84 & 16.74 & .91 & 3,373 & .79 & ,83 \\
\hline M8 & 0.87 & 17.38 & .93 & 3,343 & .81 &, 82 \\
\hline
\end{tabular}




\section{Doğrulayıcı Faktör Analizi}

Elde edilen verilerin analizinde doğrulayıcı faktör analizi için Lisrel 8.71 programı (Joreskog ve Sorbom 2004) kullanılmıştır. Orijinal ölçek yapısının uygunluğunu test etmek için, orijinal ölçek ve birinci çalışmadaki model kullanılmıştır.

Modelin sinanmas1 sonucunda $\mathrm{X}^{2}=(19, \mathrm{~N}=224) 86.25$, RMSEA $=$ $0.075, \mathrm{SRMR}=0.058, \mathrm{GFI}=.91$ ile kabul edilebilir $\mathrm{CFI}=.97$ ve NFI $=.96$, $\mathrm{NNFI} / \mathrm{TLI}=.95$ ile iyi düzeyde uyum değerlerine sahip olduğu saptanmıştır.

Ölçeğin modele uygunluğu için yapılan yapısal eşitlik modeline dayalı DFA testinde elde edilen bir diğer sonuç, örtük değişkenlerle yol analizidir. Tablo 4' de ölçek maddelerine ilişkin DFA analizi sonucu elde edilen standardize edilmiş değerler .56 ile 93 arasında değişmektedir. Yine her bir maddenin ölçeğe katkıları bakımından $\mathrm{R}^{2}$ değerleri oldukça yüksektir. DFA sonuçları, ölçeğin yapısının uygun bir yapıda olduğunu ortaya koymaktadır. Diğer bir deyişle, ölçeğin faktör yapısı orijinal ölçek ile uyumlu bir yapıdadır.

\section{Güvenirlik}

\section{Madde Toplam Puan Korelasyonu}

Ölçek maddelerinin güvenirliğini ölçmek amacıyla yapılan madde toplam puan korelasyonu, .40 ile .74 arasında değişmekte olup tüm maddeler .01 düzeyinde anlamlıdır.

\section{Alfa Değerleri}

Ölçeğin toplam ve alt ölçeklerinin içsel güvenirliğini belirlemek için yapılan cronbach alfa değerleri tüm ölçek için .80, Duygusal Sosyal Destek Alt Ölçeği için .72, ve Araçsal Sosyal Destek Alt Ölçeği için .88 olarak hesaplanmıştır.

\section{TARTIŞMA ve SONUÇ}

$\mathrm{Bu}$ çalışmanın amacı, Schulz ve Schwarzer (2003) tarafından geliştirilen Berlin Sosyal Destek Ölçeklerinden Algılanan Elde Edilebilir Destek Ölçeğinin, üniversite öğrencileri üzerinde Türkçeye uyarlamasının yapılmasıdır. Bu amaçla, iki farklı çalışma gerçekleştirilmiştir.

Hem birinci çalışma hem de ikinci çalışma kapsamında ölçeğin yapı geçerliği için doğrulayıcı faktör analizi yapılmıştır. Sonuçta ölçeğin orijinal ölçekte olduğu gibi iki faktörlü yapısı doğrulanmıştır. Doğrulayıcı faktör analizi sonucunda ölçeğin uygunluk değerlerinin iyiden mükemmele doğru bir yapı içerdiği saptanmıştır. Ölçeğin duygusal ve araçsal olmak üzere iki 
farklı alt ölçekten oluştuğu belirlenmiştir. Semmer ve ark., (2008) duygusal (şefkat ve değer verme gibi) ya da araçsal (bilgisel ve maddi yardım gibi) sosyal desteği, işlevsel sosyal destek olarak tanımlamaktadırlar.

Ölçeğin ayırt edici geçerliğini belirlemek amacıyla birinci çalışmada depresyon, anksiyete ve umutsuzluk gibi değişkenlerle ilişkisine bakılmıştır. İkinci çalışmada, ölçeğin bileşen geçerliğini belirlemek için psikolojik iyi olma ölçeği kullanılmıştır. Sonuçta, AEED toplam ve araçsal Destek ölçek puanları ile anksiyete depresyon ve umutsuzluk ölçek puanları arasında olumsuz yönde anlamlı ilişki elde edilmiştir. Yazın alanındaki bulgularla bu bulgunun paralel olduğu görülmektedir (Abramson ve ark., 1989; Bayat ve ark.., 2008; Beedie ve Kennedy, 2002; Cohen ve McKay,1984; George ve ark., 1989; Horstmanshof ve ark., 2008; Maher ve ark. 2006; Sheets ve Mohr, 2009; Yıldırım, 2004; Zimet ve ark., 1990). Bu ilişkide yalnızca duygusal sosyal destek alt ölçeği ile umutsuzluk arasında anlamlı ilişki bulunmamıştır. $\mathrm{Bu}$ sonucu destekleyen herhangi bir çalışmaya rastlanmamıştır. Diğer bir deyişle, umutsuzluk ölçeği duygusal sosyal desteği ayırt etmemektedir.

Kizlar erkeklerden daha fazla hem duygusal hemde araçsal sosyal destek puanları aldığı saptanmıştır. Alan yazında, kızlara daha fazla sosyal destek verildiğine dair çalışmalara rastlanmıştır (Kapıkıran ve Özgüngör 2009; Lopez ve ark., 2002; Malecki ve Demaray 2003).

Sosyal desteğin benzer yapılarla ilişkisine bakmak için ikinci çalışmada, Psikolojik İyi Olma Ölçeği (PİOÖ) uygulanmıştır. AEDÖ ile PİOÖ ve alt ölçeklerinin tümünün birbirleriyle olumlu yönde anlamlı ilişkisi olduğu saptanmıştır. Yazın alanında Algılanan Elde Edilebilir Destekle psikolojik iyi olma, öznel iyi olma ve yaşam doyumu gibi birbirine yakın özelliklerle olumlu yönde ilişkisi olduğuna yönelik çok sayıda araştırma mevcuttur. (Burris ve ark., 2009; Cohen ve McKay, 1984; Cummings, 2002; Danielsena ve., 2009; Demaray ve Malecki, 2002; Edwards ve Lopez, 2006; Horstmanshof ve.ark., 2008; Sheets ve Mohr 2009; Wilson ve ark., 2006).

$\mathrm{Bu}$ araştırmanın birinci çalışmasında yapılan Cronbach alfa, test tekrar test ve madde toplam korelasyonu analizleri, ölçeğin yeterince güvenilir olduğunu ortaya koymuştur. Ayrıca ikinci çalışmada yapılan Cronbach alfa, madde toplam korelasyonları bakımından yeterli olduğu yeniden belirlenmiştir.

Araştırmanın bazı sınırlılıklarıda mevcuttur. Bunlardan birisi, ölçeğin uyarlama çalışması için kullanılan örneklemin yalnızca bir üniversite ve fakülteden alınmış olmasıdır. Çalışmanın bir diğer sınırlılığ çalışmanın katılımcı grubunun düşük olmasıdır. Üçüncüsü, birinci çalışmada kullanılan 
katılımcı grup bir kısmı ile hem test tekrar test güvenirliğinin yapılmış olması, hem de ölçeğin diğer psikometrik özelliklerinin belirlenmesi için kullanılmasıdır. Dördüncü bir sınırlılığı, araştırmanın hem fiziksel hem de psikyatrik hastalardan oluşan bir örneklem üzerinde de yapılmamış olmasidir.

Dolayısı ile AEED ölçeği ergen, yetişkin ve yaşlı gruplar üzerinde çalışma yapılmasına izin vermez. Ayrıca, üniversite öğrencilerine yönelik çalışma yapılmasını güçleştirmektedir. $\mathrm{Bu}$ nedenle farklı üniversitelerde öğrencilerle yapılacak çalışmalar ölçeğin psikometrik özelliklerine katkı yapacaktır. Ek olarak, ölçeğin ergen, yetişkin ve yaşl1 gruplarla geçerlik ve güvenirliğinin yapılması ölçeğin daha yaygın olarak kullanımını artıracaktır.

Tüm bu sınırlılıklarına rağmen, mevcut çalışmanın bazı katkıları vardır. Bunlardan birisi, AEEDÖ'nin duygusal ve araçsal olmak üzere iki farklı sosyal destek türünü ölçebilecek bir ölçeğin Türkçeye kazandırılmasıdır. Bu ölçek ile algılanan elde edilebilir desteği içeren çalışmaların yapılmasını sağlayabilir. Özellikle ölçek, ölçmekte olduğu duygusal ve araçsal sosyal desteğin etkilerini belirlemeye yönelik çalışmaların yapılmasına olanak verebilir.

\section{KAYNAKLAR}

Abramson, L.Y., Metalsky, G.I., Alloy, L. B. (1989). Hopelessness depression: A theory based subtype of depression. Psychological Review, 96(2): 358-372.

Akin, A. (2008). Scales of Psychological Well-being: A study of validity and reliability. Educational Science: Theory and Practice, 8(3), 721-750.

Barrera, M., and Ainlay, S. L. (1983). The structure of social support: A conceptual and empirical analysis. Journal of Community Psychology, 11, 133-143.

Barry RA., Bunde, M. Brock RL. and Lawrence, E (2009). Validity and Utility of a Multidimensional Model of Received Support in Intimate Relationships. Journal of Family Psychology. Vol. 23, No. 1, 48-57.

Bayat, M., Erdem, E. ve Kuzucu, E.G.(2008) Support Levels of the Parents of Children With Cancer. Journal of Pediatric Oncology Nursing, 25, (5) 247-253.

Beedie, A. and Kennedy, P. (2002). Quality of Social Support Predicts Hopelessness and Depression Post Spinal Cord Injury. Journal of Clinical Psychology in Medical Settings, 9(3): 227-234. 
Burris, J. L., Brechting, E. H., Salsman, J.and Carlson C. R. (2009) Factors Associated With the Psychological Well-Being and Distress of University Students. Journal of American College Health, 57( 5) 536 544.

Cenkseven, F. (2004). Üniversite Öğrencilerinin Öznel ve Psikolojik İyi Olmalarını Yordayan Değişkenlerin İncelenmesi. Yayınlanmamış Doktora Tezi, Çukurova Üniversitesi.

Cobb, S. (1976). Social support as a moderator of life stres. Psychosomatic Medicine, 38,(5) 300-314.

Cohen, S., and McKay, G.(1984). Interpersonal relationships as buffers of the impact of psychological stress on health. In: A. Baum, J.E. Singer and S. Taylor, Editors, Handbook of Pychology and Health, Erlbaum, Hillsdale, NJ.

Costanzo, E. S., Ryff, C. D. and Singer, BH (2009) Psychosocial Adjustment Among Cancer Survivors: Findings From a National Survey of Health and Well-Being. Singer, B. H. Health Psychology, 28(2) 147-156.

Cummings, S.M. (2002). Predictors of psychological wellbeing among assisted-living residents. Health and Social Work, 27(4), 293-302.

Danielsena, A. G., Samdal, O, Hetland, J, and Wold, B. (2009). Schoolrelated social support and students' perceived life satisfaction. Journal of Educational Research, 102(4):303-318.

Demaray, M. K., and Malecki, C.K. (2002). Critical levels of perceived social support associated with student adjustment. School Psycholgy Quarterly. 17: (3), 213-241.

Dolbier C.L. and Steinhardt M.A. (2000) The Development and Validation of the Sense of Support Scale. Behavioral Medicine, 25, (4)169-179.

Eker, D. ve Arkar, H. (1995). Çok boyutlu Alg1lanan Sosyal Destek ölçeğinin faktör yapısı geçerlik ve güvenirliği. Türk Psikoloji Dergisi, 10(34):45-55.

Edwards, L..M. and Lopez, S.J. (2006). Perceived family support acculturation, and life satisfaction in Mexican American Youth: a Mixed-Methods Exploration. Journal of Counseling Psychology, 53 (3) 279-287. 
Eskin, M, Ertekin, K, Harlak, H ve Dereboy Ç.G (2008) Lise öğrencisi ergenlerde depresyonun yaygınlığı ve ilişkili olduğu etmenler. Türk Psikyatri Dergisi, 19(4):382-389.

George L.K, Blazer D. G, Hughes D.C and Fowler N. (1989). Social support and the outcome of major depression. The British Journal of Psychiatry 154: 478-485.

Goering, P. N., Lancee, W. J. and Freeman, S. J. (1992). Marital support and recovery from depression. The British Journal of Psychiatry 160: 76-82.

Gökler, I. (2007). Çocuk ve ergenler için sosyal destek değerlendirme ölçeği Türkçe formunun uyarlama çalışması: faktör yapısı, geçerlik ve güvenirliği. Çocuk ve Gençlik Ruh Sağllğ Dergisi, 14 (2) : 90-99.

Greenglass, E. R. and Fiksenb, L. (2009). Proactive Coping, Positive Affect, and Well-Being Testing for Mediation Using Path Analysis. European Psychologist, 14(1) 29-39.

Gün, Z. ve Bayraktar, F. (2008). Türkiye'de iç göçün ergenlerin uyumundaki rolü. Türk Psikyatr Dergisi, 19(2): 167-176.

Herrero, J. and Gracia E. (2007). Measuring perceived community support: Factorial structure, longitudinal invariance, and predictive validity of the PCSQ (perceived community support questionnaire) journal of Community Psychology, 35, (2), 197-217.

Horstmanshof, L., Punch R., and Creed, P. A. (2008) Environmental correlates of wellbeing among final-year high school students. Australian Journal of Psychology, 60(2), 101 - 111.

$\mathrm{Hu}$, L. and Bentler, P. M. (1999). Cut off criteria for fit indexes in covariance structure analysis: Conventional criteria versus new alternatives. Structural Equation Modeling, 6, 1-55.

Jahn, E. W., Thompson, C. A. and Kopelman, R. E. (2003) Rationale and construct validity evidence for a measure of perceived organizational family support (POFS): because purported practices may not reflect reality. Community, Work and Family, 6(2)123 - 140.

$\mathrm{Hu}$, L. and Bentler, P. M. (1999). Cut off criteria for fit indexes in covariance structure analysis: Conventional criteria versus new alternatives. Structural Equation Modeling, 6, 1-55.

Jöreskog, k. and Sörbom, D. (2004). LISREL 8.71 ve PRELIS 2.71. Scientific Software International, Inc. Lincolnwood, IL 60712, U.S.A. 
Kapıkıran, Ş. ve Özgüngör, S. (2009). Ergenlerin sosyal destek düzeylerinin Akademik başarı ve güdülenme düzeyi ile ilişkileri. Çocuk ve Gençlik Ruh Să̆llğg Dergisi, 16(1): 21-30.

Kelloway EK (1998). Using LISREL for structural equation modeling. SAGE publication, Inc. California s.56.

Kleiboer, A. M., Kuijer, R. G., Hox, J. J., Schreurs, K. M. G. and Bensing, J. (2006). Receiving and providing support in couples dealing with multiple sclerosis: A diary study using an equity perspective. Personal Relationships, 13, 485-501.

Lambert, V. A. Lambert, C.E., Klipple. G. L.,and Mewshaw, E. A. (1990) Relationships among hardiness, social support, severity of illness, and psychological well-being in women with rheumatoid arthritis. Health Care for Women International. 11:159-173.

Lopez, E.j., Ehly, S., and Vazquez-Garcia, E. (2002). Acculturation, Social Support and Academic Achievement of Mexican and Mexican American High School Students: An Exploratory Study. Psychology in the Schools, 39: (3), 245-257.

Maher, M.J., Mora, P.A. and Leventhal, H. (2006). Depressyon as a Predictor of Perceived Social Support and Demand: A Compenential Approach Using a Prospective Sample of Older Adults. Emotion, 6(3), 450-458.

Malecki C. K. and Demaray, M. K. (2003) What Type of Support Do They Need? Investigating Student Adjustment as Related to Emotional, Informational, Appraisal, and Instrumental Support. School Psychology Quarterly, Vol. 18, No. 3, 231-252.

Malecki, C. K., and Demaray., M. K. (2002). Measuring perceived social support: development of the child and adolescent social support scale (CASSS). Psychology in the Schools. 39(1), 1-17.

Malecki, C. K., and Demaray., M. K. (2006). Social support as a buffer in the relationship between socioeconomic status and academic performance. School Psychology Quarterly, 21(4). 375-395.

Ratella, C.F., Larose, S., Guay, F. \& Senecal, C. (2005). Perceptions of parental involvement and support as predictors of college students' persistence in a science curriculum. Journal of Family Psychology. 19: (2), 286-293. 
Ryff, C. D. (1989a). Happiness is everything, or is it? Explorations on the meaning of psychological well-being. Journal of Personality and Social Psychology, 57, 1069-1081.

Semmer, N. K., Elfering, A., Jacobshagen, N. et al. (2008). The emotional meaning of instrumental social support. International Journal of Stress Management, 15(3):235-251.

Schwarzer, R. Knoll, N. and Rieckmann, N. (2004). Social support. Introduction to health psychology In A. Kaptein \& J.Weinman (Eds.), Oxford, England: Blackwell, 158-182).

Schmidt, T.J., Klessig, J.L. ve Pufahl, T.M, (2006). The Provision of emotional support to men and women. Midwestern Psychological Association Convention Presentation.

Schulz, U. and Schwarzer, R. (2003). Soziale Unterstützung bei der Krankheitsbewältigung. Die Berliner Social Support Skalen (BSSS) [Social support in coping with illness: The Berlin Social Support Scales (BSSS)]. Diagnostica, 49: 73-82.

Sheets, R. L., Jr. and Mohr J. J. (2009). Perceived Social Support From Friends and Family and Psychosocial Functioning in Bisexual Young Adult College Students. Journal of Counseling Psychology. 56( 1) 152163.

Savaşır, I. ve Şahin, N. H. (1997). Bilişsel-Davranışçı Terapilerde Değerlendirme: Sik Kullanılan Ölçekler. Türk Psikologlar Derneği Yayınlar1, Ankara. S 61-70,115-122.

Şimşek, (2007) Yapısal Eşitlik Modellemesine Giriş Temel İlkeler ve LISREL uygulamaları. Ekinoks Yay. Ankara.

Tardy, C. (1985). Social support measurement. American Journal of Community Psychology, 13, 187-202.

Thoits, P. (1982). Conceptual, methodological, and theoretical problems in studying social support as a buffer against life stress. Journal of Health and Social Behavior, 23, 145-159.

Thoits, P. (1995). Stress, coping, and social support processes: Where are we? What next? Journal of Health and Social Behavior, (extra issue), 53-79.

Uchino, B., Cacioppo, J. and Kiecolt-Glaser, J. (1996). The Relationship Between Social Support and Physiological Processes A Review with 
Emphasis on Underlying Mechanisms and Implications for Health. Psychological Bulletin. 119: (3), 488-531.

Vaux, A., Phillips, J., Thomson, B., Holly, L., Williams D., and Stewart, D. (1986). The Social Support Appraisals (SSA) Scale: Studies of reliability and validity. American Journal of Community Psychology, 14, 195-220.

Wentworth, R. and Parks, C. (2006). Social Support and Self Esteem: Contributing Factors in Community İnvolvement. Midwestern Psychological Association Convention Presentation.

Wilson, S., Washington, L.A., Engel, J.M. et al. (2006). Perceived social support. psychological adjustment and functional ability in youths with physical disabilities. Rehabilitation Psychology. 51:( 4), 322-330.

Yıldırım, İ. (2004). Depresyonun yordayıcısı olarak sınav kaygısı, gündelik sikıntılar ve sosyal destek. Haccettepe Universitesi Eğitim Fakültesi Dergisi, 27, 241-250.

Yıldırım, İ. (2004a). Algılanan Elde Edilebilir Destek Ölçeğinin Revizyonu. Eğitim Araştırmaları (Eurasian Journal of Educational Research), 17, 221-236.

Zimet, G. D., Dahlem, N. W., Zimet, S. G. ve Farley, G.K. (1988). The multidimensional scale of perceived social support. Journal of Personality Assessment: 52, 30-41. 
EK

\section{Algılanan Elde Edilebilir Destek Ölçeği}

\begin{tabular}{|c|c|c|c|c|c|}
\hline & & Hiç & $\mathbf{A z}$ & Çok & $\begin{array}{l}\text { Pek } \\
\text { Çok }\end{array}$ \\
\hline & Duygusal Sosyal destek & & & & \\
\hline 1 & $\begin{array}{l}\text { Gerçekte benden hoşlanan insanlar } \\
\text { var. }\end{array}$ & 1 & 2 & 3 & 4 \\
\hline 2 & $\begin{array}{l}\text { Ne zaman kendimi kötü hissetsem, } \\
\text { başka insanlar şefkat gösterir. }\end{array}$ & 1 & 2 & 3 & 4 \\
\hline 3 & $\begin{array}{l}\text { Ne zaman üzgün olsam, beni } \\
\text { neşelendirecek insanlar olur. }\end{array}$ & 1 & 2 & 3 & 4 \\
\hline \multirow[t]{2}{*}{4} & $\begin{array}{l}\text { Rahatlamaya ihtiyaç duyduğumda, } \\
\text { beni rahatlatacak her zaman birileri } \\
\text { vardır. }\end{array}$ & 1 & 2 & 3 & 4 \\
\hline & Araçsal Sosyal destek & & & & \\
\hline 5 & $\begin{array}{l}\text { Daima güvenebileceğim birkaç insan } \\
\text { vardır. }\end{array}$ & 1 & 2 & 3 & 4 \\
\hline 6 & $\begin{array}{l}\text { Endişelendiğim zaman, bana yardım } \\
\text { edecek birileri vardır. }\end{array}$ & 1 & 2 & 3 & 4 \\
\hline 7 & $\begin{array}{l}\text { İhtiyaç duyduğumda, bana yardım } \\
\text { öneren insanlar vardır }\end{array}$ & 1 & 2 & 3 & 4 \\
\hline 8 & $\begin{array}{l}\text { Üstesinden geleceğim çok şey } \\
\text { olduğunda, bana yardım edecek } \\
\text { birileri vardır }\end{array}$ & 1 & 2 & 3 & 4 \\
\hline
\end{tabular}


